損検出能が優れ，心筋シンチはデータ収集，処理に時䦩 を要するが検出能は良い. 肝シンチでは $4 \mathrm{~cm}$ 以下の久 久 損検出に15\%以上の感度上昇があった．頭部断層では， Kr によるプール像は有效であった等の回答があった。 木下（千葉がんセンター）より ECT 像は $\mathrm{Ga}$ 検査では 骨の影響が少なく有效であるとの追加発言があった。べ ビーサイクロトロンの普及により，新しい核種および放 射性薬品の開発は断層撮影の技術を大きく影響し, ECT, その他の断層像の有用性は，さらに高くなるであるう.

\section{RI-6 データ処理-2}

座長 木下富士美（千葉がんセンター）

127. ${ }^{81 \mathrm{~m}} \mathrm{Kr}$ による換気・血流比分布の測定

東京慈恵会医科大学附属病院

○橋本広信・深沢 渉・藤隊，実

藤岡誠・岡本日出夫

〔目的〕われわれは，今回比較的簡単な肺の換気 ( $\dot{\mathrm{V}})$ 血流 $(\dot{Q})$ 分布の不均等の程度をコンピュータをむちいて 定量的に評価した。

〔方法】換気・血流画像の ROI 内のマトリックス素 子について, 各 $\dot{V} / \dot{Q}$ 比を求め, 座標の横軸に取り, 縦 軸に $\dot{V} / \dot{Q}$ 比住対する換気・血流量をカウント率で表わ した.

〔結果〕正常者の換気・血流分布は, $\dot{\mathrm{V}} / \dot{\mathrm{Q}}$ 比 1.0 附近 を中心に正視分布を示した．慢性気管支炎では， $\dot{V} / \dot{Q}$ 比 1.0 と0.5附近にピークをるつ 2 相性を示した. 0.5附 近のピークは，血流より肺胞に移行した ${ }^{81 \mathrm{~m}} \mathrm{Kr}$ が，気道 狭窄のため洗い出されず，停滞し，血流の短絡が過大評

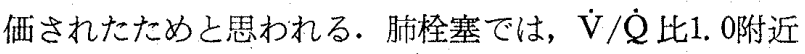
のピークと死腔効果を反映して 2.0 以上にピークをむつ 2 相性の分布として表示された。

128. 経時的唾液腺シンチグラフィ定量評価の検討

慶応義塾大学放射線業務管理室 RI 部門

○清水正三・北川五十雄・三宮敏和 井野真裕・清水正勝

〔目的〕 経時的唾液腺シンチグラフィによる，シュー グレン症候群の診断能力の向上のために, 唾液腺機能放 射図の定量的評価について検討を行った。

〔方法】：経時的睡液腺シンチグラフィによって得られ る活液腺機能放射図より，アイソトープの摂取・分泌機 能を示すパラメータを測定し; シェーグレン症候群, Subclinical シェーグレン症候群, 正常, の確定診断の得 られた 3 群についてパラメータの比較を行った。

〔結果〕求められたパラメータは病態間で有意の差を
示めし，経時的唾液腺シンチグラフィの定量的評価はシ ューグレン症候群の早期発見, 経過観察に有效であると 考えた。

〔訂正〕予稿集本文および表1の（B/A×100\%）は $(\mathrm{A}-\mathrm{B} / \mathrm{A} \times 100 \%)$.

129. カウント比によるび慢性肝疾患の判定について 久留米大学病院 RI 臨床部門

○執行一幸・山下龍雄・野口耕治

〔目的〕従来のび慢性肝疾患の判定について, 主とし て, 形態的にで慢性肝疾患の判定をされていた. 今回, われわれはルチン化を目的とし，手技的㶕易で， RI 活 性の面より機能的に判定する法として, 肝右葉, 肝左葉 脾藏の各カウント比によるコンピュータ処理について検 討した.

〔結果】今回の結果より正愻率は正常78\%，慢性肝炎 $38 \%$, 肝硬変 $91 \%$ であた. RI 活性よりの判定のため, 肝機能障害の高い肝硬変, 血液次患には特に有効で経過 観察の指標となる. 今後, 臨床データを参考にして, 本 法より病気が軽快化方向にあるのか, 惠化しているのか を判断できるような病状経過の数量化について検討して いきたい。

130. オートフルオロスコープとパーソナルコンピュー タのオンライン化によるデータ処理

東海大学病院放射線科

○村上 剛・福田利雄 室伊三男・湯之上末日

オートフルオロスコープにより得られたデータを処理 するにあたり，本体のコンピュータでは処理能力が少な く，他のコンピュータでの処理が必要である，そてでわ れわ机は，オートフルオロスコープとパーソナルコンピ ュータの, MT を介してのオンライン化によるデータ処 理を試み，実用化している. 現在の処理内容は，1レ， グラム解析，(2)シャント流量率測定，(3)E.F. 測定，(4)局 所脳循環測定，(5)心シャント率測定，等である.オンラ イン化により入力ミスが皆無となり，省力化にも役立ち， オートフルオロスコープの活用範囲が拡がった. 今後, DMA 方式，また，処理能力の高いコンピュータとの接 続を考え，より進んだソフトウェアを開発する予定であ る.

131. ${ }^{81 \mathrm{~m}} \mathrm{Kr}$ による $\mathrm{CO}_{2}$ 負荷前後の $r \mathrm{CBF}$ の定量化 愛媛大学医学部附属病院

○中田 茂・渡部真二 上田幸介・川上寿昭

〔目的】 ${ }^{81 \mathrm{~m}} \mathrm{Kr}$ 連続注入時における頭部関心領域内の 